govern throughout his life with just laws. After this the king received such support that he was able to gather an army so formidable as to render Robert's undertaking hopeless, despite the desertion of the maiores regni. It was doubtlessly in furtherance of this agreement between the king and the barons that this writ was issued, for by it the shire-moot is ordered to take oath (assecurare sacramento) to defend the realm against Robert, and the dignitaries mentioned by name (this is clearly the meaning of vobis predictis) are directed to receive this security from the king's demesne tenants (homines), and are informed that his barons will cause them to receive the like from all their men, as the barons had granted to him. This grant is not recorded elsewhere, bat it is a nataral complement of their assurances to the king recorded by Eadmer. The charter supports the accuracy of this writer's account of the proceedings, and we can on the strength of this agreement assign it to some date between 9 June and 20 July 1101, probably to the end of June or the beginning of July, for the great army assembled by Henry in consequence of this agreement had gathered long enough before 1 August to convince Robert of the futility of his attack, and also long enough for symptoms of disloyalty cansed by the treachery of some of the barons to develope and for Anselm by an address to the army to allay them.

With this ascription the names of the persons to whom the charter is addressed and of the witnesses agree, although they do not restrict the date to this time. Osbert, the sheriff of Lincoln, is known to have filled that office in the reign of William II and in the early years of Henry I. ${ }^{16}$ Picot, son of Colswain, was a prominent Lincolnshire landowner of the time. ${ }^{17}$ The three lay witnesses were Henry's staunchest supporters and personal friends. Anselm (whose name is written $A$ nsello by what is probably a clerical error) rendered even greater services to Henry at this critical time, and he fitly witnesses the writ for perfecting the arrangements in which he had played so large a part.

W. H. Btetenson.

\title{
The Flemings in Eastern England in the Reign of Henry II.
}

The question of the immigration of Flemings into England during the twelfth century, whether as mercenary soldiers or settlers, or indeed in both capacities, is one of great interest and importance.

10 Round, Ancient Chartars, p. 2. He is the sherifl of Lincoln to whom is addressed a writ of Henry I, dated at Winchester, 31 July 1100, concerning the grant of Nettlebam to the bishop of Lincoln, which is copied into the early thirteenthcentury Ragistrum Antiquissimum, fo. $8 \mathrm{~d}$, at Lincoln, and which was confirmed by an inspeximus of Edward I on 6 Febrasy 1284, also preserved at Lincoln.

"Ronnd, Feudal Einglard, p. 158. 
Dr. Cunningham ${ }^{1}$ brings some good evidence to show that (1) Flemish immigration into England was common before the time of Henry II, (2) that this included settlers of an industrial character as well as mercenary soldiers, and (3) that these mercenaries were capable of being converted into peacefal artisans. He then quotes a passage from William of Newburgh to the effect that on the accession of Henry II the mercenaries passed away from England like a dream, and adds-

Still there is no resson to sappose that this edict extended to all Flemings, but only to the military adventurers who would not betake themselves to honest labour. Enough has been said to show that there was a constant stream of immigration, which began at the Conquest and continued during the twelfth century. ${ }^{2}$

Dr. Cunningham points out that Flemish mercenaries were freely used during the civil war of $1173-4$, and he then proceeds to argue that the industrial development of the twelfth and thirteenth centuries in general and the character of the gilds in particular are best explained if we suppose ' that the weavers' gilds were the political organisation of aliens, who were neither deported from England by Henry I nor expelled by Henry II, though they were not at once absorbed into the life of the towns where they lived.'s

Dr. Cunningham has made a very strong case, but there is still a lack of direct evidence sbowing (1) that in the second half of the twelfth century Flemings other than mercenaries came to England and (2) that any of those who came to fight remained to weave. Fortunately, as it happens, evidence pointing in this direction has come to light in certain entries in the recently published pipe rolls for the twenty-second and twenty-third years of Henry $\amalg$, which tend to support Dr. Cunningham's hypothesis. In the Yorkshire accounts, in the twenty-second year, we read-

Hakun de Scardeburc redd. comp. de .xri. $m$ pro lana Flandr[ensium] quam habuit et de .viii. $m$ pro misericordia.

Haldenus prepositus redd. comp. de .xi. $l$. de misericordia pro eadem lana,

and three other men are amerced for the same cause. ${ }^{4}$ Now follow other instructive entries :

Ærn' debet dimidiam marcarn de misericordia pro catallis Flan. $\mathrm{dr}[$ ensium].

1 Cirowth of English Industry and Connorce, Cambridge, 4th edition, 1905, i. App. E. His riews on the question were criticised by Professor Ashley in the Political Science Quarterly, vi. 155 ; but Dr. Cunningham, having gone orer the subject again, has tound no reason for altering his opinion.

I Ibid. pp. 648-9.

- Op. ctt. p. 655.

- The Great Roll of the Pipe for the 'Twenty-second Fear of King Henry II (Pipe Roll Society, 1904), p. 104. 
Robertus le Brun redd. comp. de .r. $m^{\prime}$ quia communicauit Flandr[ensibas] [cum inimicis Regis in the Chancellor's Roll].

Gerardus filius Leofwini redd. comp. de .c. et .xliii. $l$ et .xiii. s. et .iiii. $d$. pro catallis Flandr[ensium] que recepit. ${ }^{5}$,

In Northampton in the same year a certain Hugh 'Cordewaner' owes three shillings and four pence quos habuat de catallis Flandr[ensium $],{ }^{6}$ and in Suffolk the sheriff accounts for a sum of money de catallis Flandrensium venditis. ${ }^{7}$ Finslly a very interesting item occurs in the Kentish account of this year:

Bicardus Corbeille monetarius redd. comp. de .xx. $m$. de crtallis Flandrensium et mercatorium forensium. ${ }^{8}$

In the eastern counties, then, in the year 1175-6 men were in commercial intercourse with the Flemings, for whom wool must have been collected and from whom other commodities appear to have been received. Now the question arises, were these Flemings actually in England, or were the transactions which are recorded in the pipe roll carried on by correspondence? The Kentish entry quoted above suggests that they were actually present, but there is further evidence, this time from Lincolnshire:

Idem vioecomes debet .xvi. l. pro Estresiis qui habuerant catalla Flandrensium et voluerunt ire in Flandriam. ${ }^{9}$

Who these Estresii may have been is not apparent, bat it certainly looks as though they were the agents and probably the fellow countrymen of the Flemings who were dealing with England at the time.

That Flemish mercenaries abounded in England daring the civil war is known from other sources. These men were introduced from four different quarters. In the first place William the Lion seems to have employed them regularly in his campaigns, and there were Flemings with him when he was captured at Alnwick in 1174. ${ }^{10}$ Then Robert of Leicester had introduced a body of mercenaries into Suffolk in the autumn of 1173." In the following spring Hugh Bigod, earl of Norfolk, received a body of upwards of 300 men from the count of Flanders. ${ }^{12}$ Finally the bishop of Durham, who was in the thick of these intrigaes, procured a foreign contingent, composed of forty French knights and 500 Flemings,

- Pipe Roll, 22 Hentry II, pp. 105-6.

- Toid. p. $50 . \quad$ Toid. p. 69

- Ibid. p. 209.

- Ibid. p. 82. The entry is repested, without the last five Fords, in the roll of the next year, p. 108.

10 Jordan Fantosme, Chronique, ed. Howlett, R.S. lines 5B0, 1725-30; Gesta Henrici Secundi, ed. Stabbs, R.S. i. 67; Hoveden, Chronica, ed. Stabbs, R.S. ii. 68.

"R. de Diceto, ed. Stabbs, R.8. i. 377. Sir James Ramsay, Angevin Empire, $174, n$. 1, shows reasons for considersbly reducing the 3,000 troops allotted to Earl Robert by Ralf de Diceto and accepted by Dr. Cunningham.

12 R. de Dieeto, i. 381 ; Gesta, i. 68. 
which, ander the command of the bishop's nephew, Hagh of Bar, landed at Hartlepool on 19 July 1174, the day on which the Scottish king was captured at Alnwick. ${ }^{13}$ Now we can to a certain extent account for the subsequent proceedings of all these Flemings. Robert of Leicester's men were defeated at Fornham by the royal army in November 1173.14 Sir James Ramsay supposed that ' the earl's rather motley force was dispersed at a blow, some killed, some drowned, some taken prisoners.' ${ }^{16}$ Bat there is evidence which suggests that some escaped to Leicester Castle, where they remained until that stronghold fell into the king's hands and was destroyed, for it is recorded in the pipe roll of the 22nd year-

Idem vicecomes debet .xxii. l. de weida Flandrensium qui fugitiui sunt et fuerunt in castello de Legercestr', ${ }^{16}$

and the same entry is repeated in the following year. ${ }^{17}$

It seems likely that the Flemings in the employ of the Scottish king disappeared from England altogether, for apparently such of his followers as were not killed or taken prisoners with him fled northward at once. ${ }^{18}$ Shortly after this the earl of Norfolk made his submission and obtained leave to send his foreign troops back to the continent in peace. ${ }^{19}$ It is probable that they all eventually returned to their native land, for although there are traces of Flemings in East Anglia in the roll of $22 \mathrm{Hen}$. II ${ }^{20}$ none are to be found in the following year.

Concerning the men whom the bishop of Durham had brought over, the Gesta Henrici records-

Et cum hoc nanciatum esset praedicto episcopo, et sciret quod rex Scotia caperetar, noluit illos quingentos Flandrenses diutius retinere, sed datis eis liberationibas et donis suis zl. dierum, permisit illos clam repatriare. ${ }^{21}$

That is to say, he allowed them to return as best they might. The bishop in short washed his hands of them, and this is the more evident from the fact that he retained his nephew and the French knights and secured special terms for them when he made his submission at the end of the month. ${ }^{22}$ Now in view of the probability that the earl of Norfolk's men, for whom special terms were made, had not completely disappeared from East Anglia two years after

13 Gesta Henricr Secundi, i. 67.

14 Diceto, i. 878. For the date see Rrmsay, op. cit. 174, n. 1.

4 Angevir Empire, p. 173 ; this is a translation of Diceto's phrase.

16 Pipe Roll, 22 Hen. II, p. 184.

1- Fantosme, lines 1802-4, 1814-6, 1842-53.

1) Gesta, i. 73 ; R. de Diceto, pp. 384-5. $\quad \Rightarrow$ Pipe Roll, 22 Her. II, p. 69.

21 Gesta, i. 67. Hoveden, ii. 63, merely writes this out with a fow trifling verbal changes.

I Gesta, i. 79. Miss Norgate, howeyer, assumes that the Flemings were sent away (presumably to Flanders) as soon as they had been paid (England under the Angevin Kings, ii. 162). 
their official departure we shall not think it likely that these 500 Flemings whom Hugh of Durham had tarned adrift in northern England would immediately have returned to their native land. Here, if anywhere, are men who might be recalled a castris ad aratra, a tentoriis ad ergasteria. ${ }^{23}$ It is scarcely unjustifiable, therefore, to connect these men with the traces of Flemings in York and Lincoln which we have discovered in the pipe rolls. The connexion is made the more natural and easy if we suppose, as we have seen reason for supposing, that the men of these counties were already engaged in commercial relations with Flemings who were either themselves present in England or were represented there by their fellow countrymen.

Gamlard Thouas Lapsley.

\section{Ithake under the Franks.}

IN works descriptive of Greece it is customary to find the statement that the island of Odysseus was ' completely forgotten in the middle ages,' and even so learned a medieval scholar as the late Antónios Meliarákes, whose recent loss is a severe blow to Greek historical geography, asserts this proposition in his admirable political and geographical work on the prefecture of Cephalonia. ${ }^{1}$ But there are a considerable number of allusions to Ithake during the Frankish period, and it is possible, at least in outline, to make out the fortanes of the famous island under its western lords.

The usual name for Ithake in Italian documents is Val di Compare, the earliest use of which, so far as I can ascertain, occurs in the Genoese historian Caffiaro's Liberatio Orientis, written in the first half of the twelfth century. ${ }^{2}$ According to $K$. Bergotês of Cephalonia this name was given to the island by an Italian captain, who was driven to anchor there one stormy night. Seeing a light shining through the darkness, he landed, and found that it proceeded from a hut in which a child had lately been born. At the request of the parents he accepted the office of godfather, or coupmápos at the child's christening, and named the valley where the hut lay Val di Compare, to commemorate the event. Whether this derivation be correct or not, the name stuck to the island for several centuries, though we shall also find the classical Ithake still surviving contemporaneously with it. The neighbouring islands of Zante and Cephalonia were severed from the Byzantine empire in 1185, at the time of the invasion of Greece

R. de Diceto, i. 297, cited by Ounningham, op. cit. pp. 648-9.

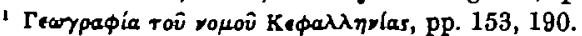

1 Pertz, Monumenta Germarias lisitorker, xviii. 46.

voL. XXI.—NO. LIXXIII. 